\title{
Hydro-Geophysical Investigations for the Purposes of Groundwater Artificial Recharge in Wadi Al-Butum Area, Jordan
}

\author{
Hani Al-Amoush \\ Earth and Environmental Sciences Department, Al Al-Bayt University, Mafraq, Jordan \\ Email: hani1@aabu.edu.jo
}

Received March 20, 2012; revised April 22, 2012; accepted May 25, 2012

\begin{abstract}
In this article, the potential for artificial groundwater recharge of Wadi Al-Butum catchments area-Jordan is studied, using geoelectrical resistivity surveys and hydro geochemical methods with the aim of storing some of surface water during flood events times to be recharged in the groundwater as an essential part of integrated water resources management. The results of geoelectrical surveys show the existence of potential zones of alluvial deposits to store and recharge the groundwater aquifers. The hydro-geochemical modeling results show an overall upgrading of the original groundwater quality could be expected.
\end{abstract}

Keywords: VES; Hydro-Geophysics; Artificial Recharge; Wadi Al-Butum

\section{Introduction}

Jordan is located in an arid to semi arid lands, and it is considered among the scarcest water resources countries in the world. About $81 \%$ of its area receives rainfall in average less than $100 \mathrm{~mm} /$ year [1]. Most of the received precipitation is being lost due to the high evaporation rates [2]. Jordan is characterized by severe weather conditions, therefore great temporal and spatial variations in rainfall; runoff and evaporation amounts are expected [3]. The annual population growth rate in Jordan is estimated to be around $2.65 \%$. Based on this percentage, it is estimated that the total population in Jordan will be around 12 millions by 2020 [4]. This will add more pressures on the existing water resources in the country leading to a massive decrease in per capita to $85 \mathrm{~m}^{3} \cdot \mathrm{capita}^{-1} \cdot \mathrm{year}^{-1}$ by 2025 [4]. One alternative to water sustainability crisis occurring in arid land is groundwater artificial recharge. It refers to the entry of water from the unsaturated zone into the saturated zone below the water table together with the associated flow away from the water table within the saturated zone [5]. The major source of water for recharging groundwater aquifers in arid and semi-arid zones is wadi runoff [6].

Wadi Al-Butum sub catchments area located in the Jordanian desert and surrounded the historical archeological site-Qasar Amra. The principle groundwater aquifer beneath Wadi Al-Butum is the Rijam formation B4 which outcrops at the surface along wadi beds in some places. Although the B4 aquifer derives the major- ity of its recharge from the north and northeast (basalt area), significant recharge does come from the area immediately surrounded the wadi [7].

According to previous studies conducted by [1], it was concluded that the runoff along Wadi Al-Butum is generated when a precipitation event exceeds in its amount 15 $\mathrm{mm}$. In the period 1969 to 2006 only three years $1998 /$ $1999,1999 / 2000$ and 2001/2002 show that all the rainfall events taking place in these years were less than $20 \mathrm{~mm}$. But the total runoffs in these years were $33,400,71,600$ and $104,900 \mathrm{~m}^{3}$ respectively. The total annual runoffs in the period 1969 to 2010 ranged from $33,000 \mathrm{~m}^{3}$ as a minimum to 65.6 million $\mathrm{m}^{3}$ as a maximum [1]. The infiltration rate in Wadi Al-Butum area was estimated to be $0.197 \mathrm{~m} /$ day [7].

Recently, several studies have been used integrated techniques in order evaluate the groundwater occurrences and locate artificial recharge zones and finding suitable sites for artificially groundwater recharge (e.g. [8,9]).

In this present study, hydro-geophysical investigations including vertical resistivity sounding surveys and hydrogeochemical modeling were carried out with the aim of studying the potential for artificial groundwater recharge in Wadi Al-Butum catchments area.

\section{Description of the Study Area}

The study area is located in the northern part of Jordan. It is situated within the coordinates longitudes $36^{\circ} 20^{\prime}$ and $36^{\circ} 35^{\prime}$ East, and Latitude $31^{\circ} 40^{\prime}$ and $32^{\circ} 00^{\prime}$ North (Fig- 
ure 1). The elevation of Wadi Al-Butum watershed area is ranging from $500 \mathrm{~m}$ above mean sea level (a.m.s.l) at the wadi bed near outlet point to $700 \mathrm{~m}$ a.m.s.l at the hilltops. The slopes may range up to $2 \%$, and the general topography becomes flat at the most eastern part of the study area. Climatologically, the study area is classified as semi-arid area; two well-defined seasons are dominating, hot, dry summer season and low wet, cold winter season [10]. The average annual minimum and maximum daily temperatures are $11.6^{\circ} \mathrm{C}$ and $26.6^{\circ} \mathrm{C}$ respectively. Humidity varies from $49.9 \%$ to $61.0 \%$ in summer and from $56.0 \%$ to $82.0 \%$ in winter [10]. The average daily evaporation observed is $10.4 \mathrm{~mm} /$ day and it varies from 5.0 to $19.0 \mathrm{~mm} / \mathrm{d}$ in summer and from 3.0 to $12.0 \mathrm{~mm} / \mathrm{d}$ in winter [11]. The average annual rainfall ranges from $50 \mathrm{~mm} / \mathrm{y}$ in the most eastern part of the study area to 130 $\mathrm{mm} / \mathrm{y}$ in the northwestern part [1].

\section{Geology of the Study Area}

The study area was mapped several times during the last few decades as part of regional mapping program [12-14]. The study area incorporates exposures of sedimentary rocks, ranging in age from Cretaceous to Quaternary. The Quaternary deposits cover in the east the underlying Tertiary deposits. The latter are intermittently exposed at the surface in the west and southwest [15]. The sedimenttary sequence includes limestone, chert, marl, chalk, sandstone, clay and evaporites. These rocks are frequently covered with a variably thick sequence of superficial deposits including alluvium, mud-silt in flats, chert pavement, Pleistocene gravels, and sand and evaporites incrustations [12]. In the subsurface a thick sedimentary section changing in thickness as well as varying in the

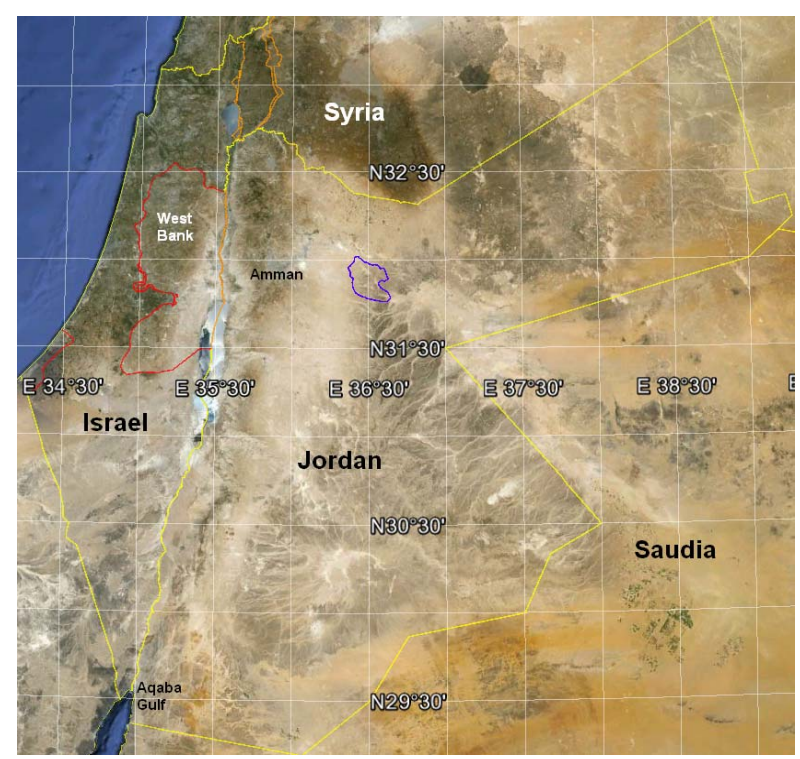

Figure 1. Location map of Wadi Al-Butum sub-catchments area (closed blue polygon-east of Amman). litho-stratigraphic and formational units underlie the study area. These sediments range in age from early $\mathrm{Pa}-$ leozoic to Pleistocene and are primarily composed of carbonates, sandstones and shale. The major thickness reduction in the sequence is towards west and southwest [15]. The Cretaceous to Tertiary deposits in the area comprise a thick sedimentary section measuring more than $350 \mathrm{~m}$ mostly of marine sediments. In Jordan the Lower Cretaceous boundary with older units is well identified by a recognizable sandstone unit of the Nubian type known as the "Kurnub Sandstone". This is identified in the area in several wells, as the sandstone formation underlying the carbonate facies of Cenomanian age. This sandstone unit varies in thickness, depth, and marks the transition zone of the major unconformity between the Jurassic and the early Cretaceous. Table 1 lists the lithostratigraphic successions in the study area with a brief description for each formation.

\section{Discussion and Results}

\subsection{Geoelectrical Data Acquisition and Processing}

Ten Vertical Electrical Resistivity Soundings (VES) were conducted along the course of Wadi Al-Butum (Figure 2), using an ABEM CAMPUS GEOPULSE Ltd. resistivity meter. Schlumberger configuration of electrodes was used in the field surveys. The profiles were directed into $\mathrm{N}-\mathrm{S}$ direction perpendicular to the Wadi Al-Butum Course. The maximum current electrodes separation extends up to $1000 \mathrm{~m}$. The increase of electrical electrodes separation lead to rapidly reduced the potential difference to be measured at potential electrodes [16]; therefore the potential electrode distances were increased gradually to get a better signal. The selection of soundings location was governed by the site conditions. The apparent resistivity values were obtained by multiplying the field resistance measurements by configuration factor at each of electrodes separation. The calculated apparent resistivity measurements were plotted against half of the current electrode spacing $(\mathrm{AB} / 2)$ on bi-logarithmic scale, a traditional interpretation techniques by curve matching and drawing auxiliary point diagram [17] was applied. Based on this preliminary interpretation, an initial estimation of resistivities and thicknesses of various geo-electrical layers was obtained. These preliminary estimations were later used as a start model incorporating known geology and the available well data for a fast computer-assisted interpretation RESIST written by [18]. The results of interpretation were also compared with the result of purely automatic inversion programs without any assumptions of layering model in which the layering model is obtained directly from a digitized sounding curve [19]. In order to get a reasonable interpretation of geoelectrical 
Table 1. Litho-strartigraphic successions in the study area (after [13,14]).

\begin{tabular}{|c|c|c|c|}
\hline \multicolumn{2}{|c|}{ Formation name } & \multirow{2}{*}{$\begin{array}{l}\text { Rock type and thickness (m) } \\
\text { Mud, laminated silt and clay }\end{array}$} & \multirow{2}{*}{$\begin{array}{c}\text { Age } \\
\text { Recent }\end{array}$} \\
\hline Holocene to & Alluvium and Mudflat & & \\
\hline $\begin{array}{l}\text { Recent } \\
\text { Sediments }\end{array}$ & $\begin{array}{l}\text { Alluvium and } \\
\text { wadi sediment }\end{array}$ & $\begin{array}{l}\text { Sand, sorted and unsorted pebble and boulders of limestone and chert of } \\
\text { local bedrock }\end{array}$ & Recent \\
\hline \multicolumn{2}{|c|}{ Superficial deposits } & $\begin{array}{l}\text { Fluviatile and lacustrine Gravels of Pleistocene/composed of } \\
\text { non-cemented, poorly-sorted deposit of chert and limestone clasts }\end{array}$ & Recent \\
\hline \multicolumn{2}{|c|}{ Wadi shallaleh chalk formation (B5) } & $\begin{array}{l}\text { Chalk, marl, glauconitic and micritic limestone, }(10-22) \mathrm{m} \text { in the central part } \\
\text { of the study area }\end{array}$ & Eocene \\
\hline \multicolumn{2}{|c|}{$\begin{array}{l}\text { Um Rijam chert limestone } \\
\text { formation (B4) }\end{array}$} & Chert, chalk, limestone, chalky limestone $(80-130) \mathrm{m}$ & Paleocene \\
\hline \multicolumn{2}{|c|}{ Muwaqqar chalk marl F. (B3) } & Chalk, limestone, marly chalk, chert, bituminous $(70-200) \mathrm{m}$ & Campanian-Danian \\
\hline \multicolumn{2}{|c|}{ Amman F. (B2) } & Limestone, chert, chalk, phosphatic $(80-90) \mathrm{m}$ & Campanian \\
\hline \multicolumn{2}{|c|}{ Ghudran F. (B1) } & Chalk, marl, marly-limestone $(10-12) \mathrm{m} \mathrm{NW}$ of the study area & Coniacian-Santonian \\
\hline \multicolumn{2}{|c|}{ Wadi El-Sir (A7) } & Crystalline limestone, marl, chert $(90-100) \mathrm{m}$ & Touranian \\
\hline \multicolumn{2}{|c|}{$\begin{array}{l}\text { Fuheis/Hummar/Shuieb }(\mathrm{F} / \mathrm{H} / \mathrm{S}) \\
\text { formations (A3 - A6) }\end{array}$} & Marl, marly limestone & $\begin{array}{c}\text { Upper Cenomanian } \\
\text { Upper-mid Cenomanian } \\
\text { Lower-mid Cenomanian }\end{array}$ \\
\hline \multicolumn{2}{|l|}{ Na'ur (A1/2) } & Thick bedded nodular dolomitic limestone, chert, marl & Lower Cenomanian \\
\hline
\end{tabular}

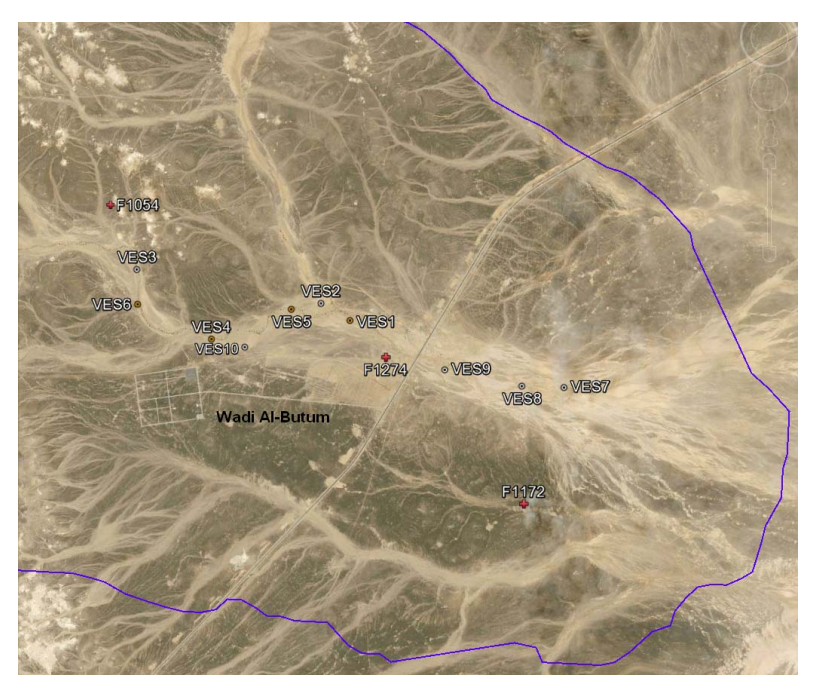

Figure 2. Location map of geoelectrical test sites and groundwater wells.

measurements about the hydro-geological setting of the study area, a correlation between the available borehole $\log$ records in the vicinity of surveyed sites have been constructed (Figure 3) and used in deducing the Lithological-resistivity interpretation A Summary list of the interpreted geo-electrical models for VES soundings are presented in Table 2, while (Figures 4-6) show three examples of VES curves and their geophysical interpretation.

\subsection{Interpretation of Geoelectrical Resistivity Data}

Figure 7 shows geoelectrical cross section along a part of the course of wadi Al-Butum area constructed from a series of vertical electrical soundings and correlated with adjacent borehole F1274. The interpretation of resistivity data led to the following findings:

The resistivity of the near surface layer is ranging between 320 and 2000 Ohm.m that characterize and typically indicative to alluvium deposits (gravel, sand). This layer reaches its maximum thickness between VES6 and VES4 $(35 \mathrm{~m})$, and does not exposed at VES1. This layer is considered of high potential for groundwater recharge.

A relatively high resistivity layer (290 - 935) Ohm.m is found beneath VES10, VES5m, VES2 and VES1. The maximum thickness of this layer is found at VES5 (20 $\mathrm{m})$. This layer is interpreted as paleo-channel alluvial deposits (Figure 2, location map) and it is considered of high potential for groundwater recharge.

Low resistivity layer (15 - 18) Ohm.m has been detected at depth of $45 \mathrm{~m}$ below ground surface at VES9 and VES8. The maximum thickness of this layer $(35 \mathrm{~m})$ has been recorded at VES9 and does not detected at the other VES sites along the section. This layer is interpreted as a saturated layer of saline groundwater which account for the high salinity of F1274 borehole (1750 $\mu \mathrm{S} / \mathrm{cm}$ ) (Table 3).

The resistivity range (35 - 150) Ohm.m extending all over the geoelectrical section (e.g. at depth $38 \mathrm{~m}$ beneath VES7, VES8 and VES9, $44 \mathrm{~m}$ beneath VES6 and $60 \mathrm{~m}$ beneath VES5) is interpreted as the main aquifer to be recharged (Rijam aquifer, B4) in the study area. The variation of resistivity reflects lithological variation and degree of saturation within the aquifer.

Two prominent high resistivity layers (500 - 15,000) 


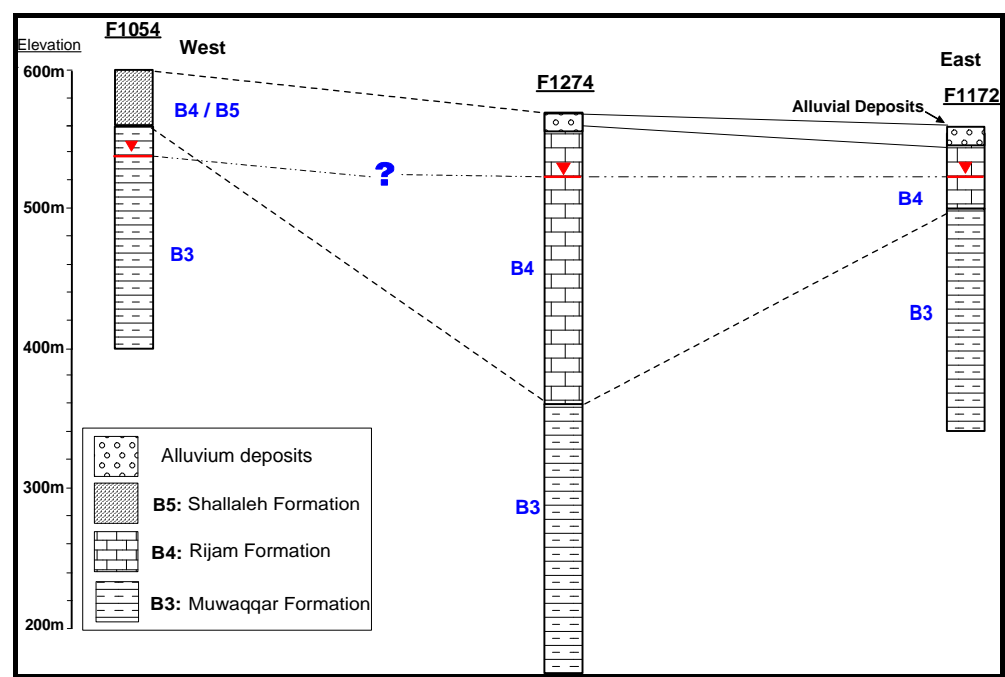

Figure 3. Correlation of the available borehole log records in vicinity of geoelectrical test sites illustrating the hydro-geological setting of the study area.

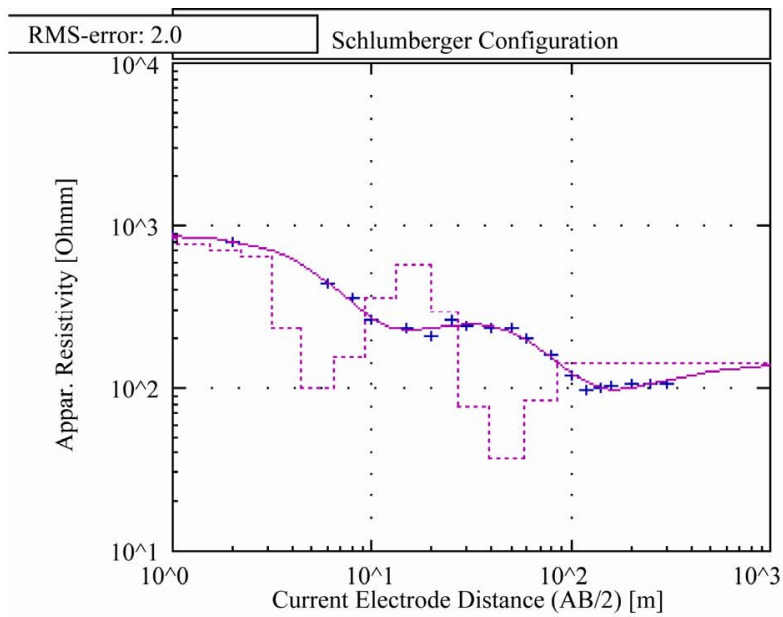

\begin{tabular}{|cccc|}
\hline NO & Res & Thick & Depth \\
\hline 1 & 889.2 & 0.7 & 0.7 \\
2 & 832.9 & 0.3 & 1.0 \\
3 & 766.4 & 0.5 & 1.5 \\
4 & 701.7 & 0.7 & 2.2 \\
5 & 643.3 & 0.9 & 3.2 \\
6 & 235.3 & 1.2 & 4.4 \\
7 & 101.2 & 2.1 & 6.5 \\
8 & 153.1 & 2.8 & 9.2 \\
9 & 359.7 & 4.0 & 13.3 \\
10 & 567.5 & 6.3 & 19.6 \\
11 & 290.2 & 7.7 & 27.3 \\
12 & 76.9 & 11.2 & 38.4 \\
13 & 36.7 & 19.2 & 57.6 \\
14 & 84.2 & 27.1 & 84.8 \\
15 & 142.0 &.-- & $\cdots$ \\
\hline
\end{tabular}

Figure 4. Modeling of a sounding point VES-5: measured apparent resistivity (blue dots), best-fit model (tabulated and as a graph in logarithmic scale) and related curve model (full line) are shown.

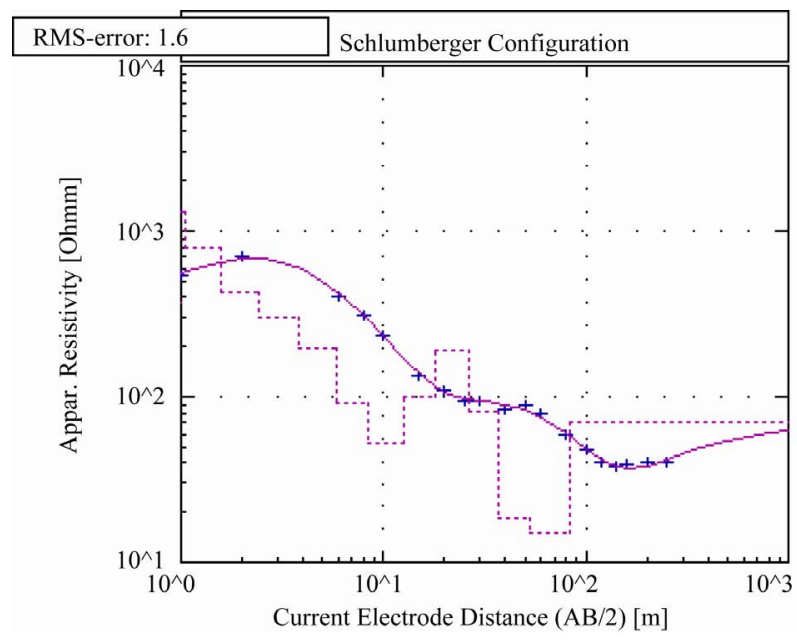

\begin{tabular}{|crcc|}
\hline NO & Res & Thick & Depth \\
\hdashline 1 & 370.9 & 0.4 & 0.4 \\
2 & 1027.2 & 0.2 & 0.7 \\
3 & 1286.9 & 0.4 & 1.0 \\
4 & 795.1 & 0.5 & 1.6 \\
5 & 430.1 & 0.8 & 2.4 \\
6 & 307.1 & 1.4 & 3.8 \\
7 & 195.3 & 2.0 & 5.9 \\
8 & 92.9 & 2.6 & 8.5 \\
9 & 52.4 & 4.1 & 12.6 \\
10 & 100.1 & 5.3 & 17.9 \\
11 & 188.8 & 8.5 & 26.5 \\
12 & 80.7 & 10.1 & 36.5 \\
13 & 18.3 & 16.8 & 53.3 \\
14 & 15.2 & 29.7 & 83.0 \\
15 & 69.8 &.-- &.-- \\
\hline
\end{tabular}

Figure 5. Modeling of a sounding VES-9: measured apparent resistivity (blue dots), best-fit model (tabulated and as a graph in logarithmic scale) and related curve model (full line) are shown. 


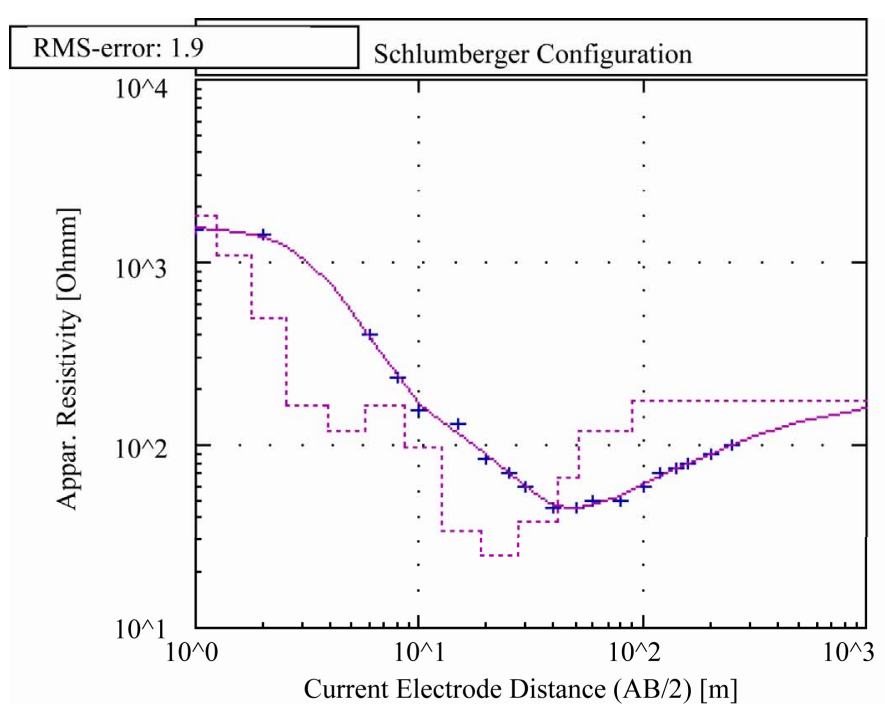

\begin{tabular}{|cccc|}
\hline NO & Res & Thick & Depth \\
\hdashline-1 & 1482.1 & 0.6 & 0.6 \\
2 & 2032.8 & 0.3 & 0.8 \\
3 & 1792.3 & 0.4 & 1.2 \\
4 & 1105.0 & 0.5 & 1.8 \\
5 & 497.1 & 0.8 & 2.5 \\
6 & 235.3 & 1.3 & 3.9 \\
7 & 165.3 & 2.1 & 6.5 \\
8 & 118.4 & 1.9 & 5.8 \\
9 & 163.3 & 2.9 & 8.7 \\
10 & 97.5 & 4.0 & 12.7 \\
11 & 34.2 & 6.1 & 28.0 \\
12 & 37.7 & 13.6 & 41.6 \\
13 & 666.5 & 9.8 & 51.4 \\
14 & 118.7 & 38.6 & 90.1 \\
15 & 174.5 &.-- &.-- \\
\hline
\end{tabular}

Figure 6. Modeling of a sounding VES-10: measured apparent resistivity (blue dots), best-fit model (tabulated and as a graph in logarithmic scale) and related curve model (full line) are shown.

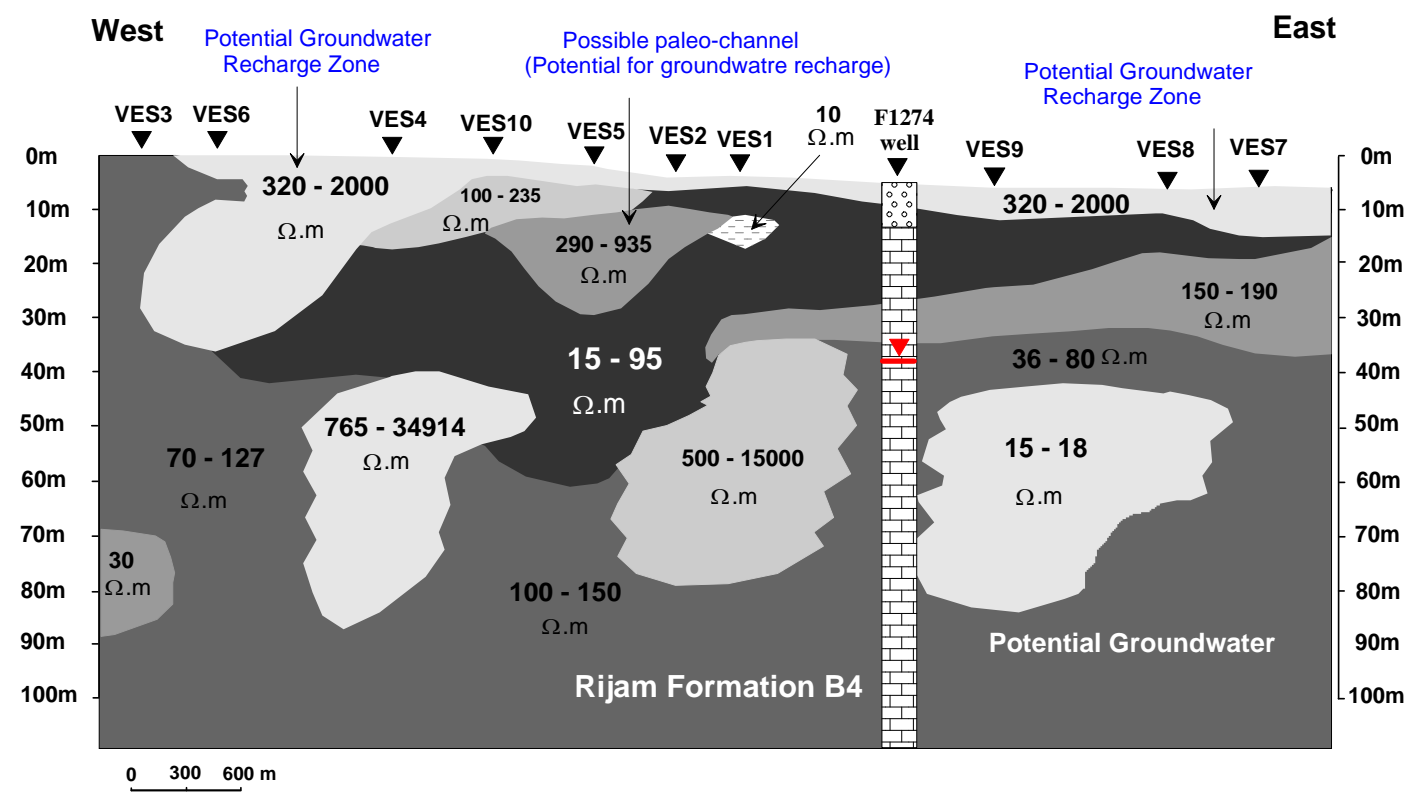

Figure 7. Resistivity depth profiles from interpreted vertical electrical sounding points along the course of Wadi Al-Butum area depicting the groundwater recharge zones potential and groundwater occurrences. Lithological data of borehole F1274 is projected onto the section (see Figure 2 for location of VES's and F1274 borehole).

Table 2. Interpretation of multilayer best-fit model of VES's.

\begin{tabular}{cc}
\hline Depth $(\mathbf{m})$ & Suggested litho-logical interpretation based on available surface geological and well log data \\
\hline G.S* $-47 \mathrm{~m}$ & VES-1 \\
$>47 \mathrm{~m}-?$ & Low resistivity fluviatile gravels, clasts of chert, limestone, with various grain sizes \\
& Highly resistive substratum bedrock \\
G.S $-59 \mathrm{~m}$ & Alluvial sediments, recent alluvial deposits of ephemeral wades, various facies of poorly sorted sediments, as shown by \\
$>59 \mathrm{~m}-?$ & a variation of resistivity values \\
\end{tabular}




\section{Continued}

\section{VES-3}

$0-32 \mathrm{~m}$

$32-100 m$

$>100 \mathrm{~m}-?$

G.S $-6.5 \mathrm{~m}$

$6.5-12.5 \mathrm{~m}$

$12.5-40 \mathrm{~m}$

$>40 \mathrm{~m}$ - ?

G.S - 3 m

3- $13 \mathrm{~m}$

$3-28 \mathrm{~m}$

$28-85 \mathrm{~m}$

G.S - 4 m

4- $9 \mathrm{~m}$

$9-35 \mathrm{~m}$

$35-86 m$

G.S* to $7.5 \mathrm{~m}$

$7.5-11.5$

$11.5-90 \mathrm{~m}$ $>90 \mathrm{~m}$

$$
\begin{gathered}
\text { G.S - } 5.0 \mathrm{~m} \\
5.0-12 \mathrm{~m} \\
12-25 \mathrm{~m} \\
25-82 \mathrm{~m} \\
>82 \mathrm{~m}
\end{gathered}
$$

G.S $-6 \mathrm{~m}$

$6-12.5 \mathrm{~m}$

$12.5-27 \mathrm{~m}$

$>27 \mathrm{~m} \mathrm{-}>80 \mathrm{~m}$

G.S $-2.5 \mathrm{~m}$

$2.5-10 \mathrm{~m}$

$10-50 \mathrm{~m}$

50 - >80 m
Low resistivity zone (39- $100 \Omega . m$ ); wadi sediments, clasts of limestone, chert, chalk, alluvial, with various grain size Relatively higher resistivity deposits, attributed to variation of litho-logical and sedimentalogical characteristics (sorting, grain size etc...) of wadi sediments and alluvial

A declining in resistivity values which could indicate to a presence of groundwater saturated zones ( correlated with F1054 well log)

VES-4

High resistivity deposits; dry alluvial sediments; wadi sediment; clasts of limestone and chert (boulder)

Higher resistivity zone; limestone chert

Low resistivity sediments; clay or saturated zones of groundwater

Highly resistive substratum bedrock

VES-5

High resistivity deposits; Gravel; wadi sediment; alluvial deposits

Low resistivity alluvial zone attributed to lithological and Lithiofacies variation

High resistivity zone; clasts of limestone, chert, chalk

Low resistivity zone (alluvial deposits); could indicate to saturated alluvial deposits?!!

\section{VES-6}

High resistivity top soil; alluvial; wadi sediment; clasts of limestone, chert

Low resistivity zone; Saturated alluvial zone

High resistive layers; dry alluvial deposits

Declining in resistivity values attributed to saturated wadi sediment of groundwater and/or to lithological variations of alluvial deposits.

*G.S: Ground Surface

VES-7

High resistivity top dry soil (alluvial sediment) (Mudflat)

Low resistivity layer; saturated alluvial sediments

Intermediate resistivity zone (160 $\Omega . \mathrm{m})$; attributed to lithological variations within the sediments (B4?)

Low resistivity substratum deposits; could indicate to the presence of saturated groundwater aquifer- Rijam aquifer-(B4)-correlated with F1172

\section{VES-8}

Highly resistive top dry alluvial sediment

Low resistivity layer; saturated alluvial sediments

High resistivity zone; lithological variations

Low resistivity deposits ( $35 \Omega . \mathrm{m}$ ); could indicate to the presence of saturated groundwater zones-Rijam aquifer-(B4)good correlation with well $\log$ (F1172)

Increasing of resistivity of substratum layer

VES-9

High resistivity top dry alluvial sediment

Low resistivity layer; Saturated alluvial sediments; Good correlation with VES-8 and VES-7.

High resistivity zone; lithological variations; Good correlation with VES-8 and VES-7

Decreasing in resistivity to about (15 - 80) $\Omega$.m which could indicate to the presence of saturated groundwater zones-Rijam formation-(B4); Good correlation with VES-8 and VES-7

\section{VES-10}

High resistive zone; wadi sediment; limestone, chert

Intermediate resistivity zone $160 \Omega$.m; attributed to lithological variations within wadi sediment.

Low resistivity zone; Saturated alluvial zones

Slightly increasing of resistivity attributed to lithological variations within Rijam formation (B4) aquifer. 
Table 3. Average chemical composition of water samples in Wadi Al-Butum catchments area (Data source; [1] in addition to recent data analyses).

\begin{tabular}{cccccc}
\hline No & Parameter & Rainfall & $\begin{array}{c}\text { Runoff } \\
\text { (flood wades) }\end{array}$ & $\begin{array}{c}\text { Groundwater (F1054) } \\
\text { B4/5 Aquifer }\end{array}$ & $\begin{array}{c}\text { Groundwater (F1274) } \\
\text { B4and B2 Aquifer }\end{array}$ \\
\hline 1 & $\mathrm{pH}$ & 7.84 & 8.04 & 8.10 & 7.50 \\
2 & $\mathrm{~T}\left({ }^{\circ} \mathrm{C}\right)$ & 17.00 & 18.10 & 21.30 & 22.00 \\
3 & $\mathrm{EC}(\mu \mathrm{S} / \mathrm{cm})$ & 165.00 & 254.9 & 530.00 & 1750.00 \\
4 & $\mathrm{~K}^{2+}(\mathrm{mg} / \mathrm{l})$ & 1.45 & 4.69 & 5.00 & 26.00 \\
5 & $\mathrm{Mg}^{2+}(\mathrm{mg} / \mathrm{l})$ & 2.43 & 5.71 & 10.00 & 39.50 \\
6 & $\mathrm{Ca}^{2+}(\mathrm{mg} / \mathrm{l})$ & 21.44 & 27.45 & 18.00 & 122.00 \\
7 & $\mathrm{Na}^{+}(\mathrm{mg} / \mathrm{l})$ & 7.81 & 14.48 & 70.00 & 189.00 \\
8 & $\mathrm{Cl}^{-}(\mathrm{mg} / \mathrm{l})$ & 20.56 & 10.63 & 80.00 & 303.00 \\
9 & $\mathrm{SO}_{4}^{2-}(\mathrm{mg} / \mathrm{l})$ & 15.84 & 15.36 & 29.00 & 396.00 \\
10 & $\mathrm{HCO}_{3}^{-}(\mathrm{mg} / \mathrm{l})$ & 56.70 & 114.04 & 120.00 & 290.00 \\
11 & $\mathrm{NO}_{3}^{-}(\mathrm{mg} / \mathrm{l})$ & 3.51 & 3.51 & 5.0 & 1.01 \\
12 & $\mathrm{Water} \mathrm{Type}$ & $\mathrm{Ca}^{2+}-\mathrm{HCO}_{3}^{-}-\mathrm{Cl}^{-}$ & $\mathrm{Ca}^{2+}-\mathrm{Na}^{+}-\mathrm{HCO}_{3}^{-}$ & $\mathrm{Na}^{+}-\mathrm{Cl}^{-}-\mathrm{HCO}_{3}^{-}$ & $\mathrm{Na}^{+}-\mathrm{Ca}^{2+}-\mathrm{Cl}^{-}-\mathrm{SO}_{4}^{2-}-\mathrm{HCO}_{3}^{-}$ \\
\hline
\end{tabular}

Ohm.m at depth 45 m beneath VES5 and $(765-34,900)$ Ohm.m at depth 40 beneath VES4 are identified.

\section{Hydrochemistry Study}

A major concern in artificial groundwater recharge studies is the resulting water chemistry when surface water joins the groundwater system and mixes with it. Mixing processes generally shift the water chemistry of the two mixed solution into a middle state between them depending on the mixing ratios [20]. In this study a theoretical hydro-geochemical modeling has been performed using the software HYDROWIN Version.3 [21] to investigate the affect of recharge surface water on the groundwater chemistry. Therefore, historical chemical analysis of water samples [1] in addition to recent analyzed water samples have been gathered and used in this study. The average chemical composition of runoff (Flood water), rainfall and groundwater samples from different aquifers in Wadi Al-Butum catchments area, and their types are listed in Table 3.

\section{Mixing Processes and Saturation Indices}

Theoretical mixing processes between the flood water and groundwater sample have been carried out using HYDRWIN program [21]. The program allows us to calculate solution specifications and saturation states of the aqueous state with respect to various minerals phases. In this study, the simulation started by adding $0 \%$ to $50 \%$ of surface runoff water to the groundwater sample of Rijam aquifer (B4) represented by F1054 well and to groundwater of B2/A7 aquifer represented by well F1274 (Table 5). The process is made five times within this range, until equal ratio of $50 \%$ to $50 \%$ was reached. The results of mixing process and saturation indices are listed in Table 4, Table 5 and Table 6 respectively.

The results of hydro-geochemical analyses and simulation process revealed the following findings:

Water/rock interaction is very limited in well F1054, as indicated by the relatively low salinity $(530 \mu \mathrm{S} / \mathrm{cm})$ and other salinity parameters (Table 3 ). This is because the Rijam aquifer (R4) from which water produced is cropping out at the earth surface or very shallow and is in direct hydraulic connection with alluvial of Wadi AlButum, which are recharged from runoff water of the Wadi. On the contrary, the high salinity $(1750 \mu \mathrm{S} / \mathrm{cm})$ and salinity parameters of Well F1274, which is produced from the deep limestone aquifer (B2/A7), in addition of B4, indicate a major water/rock interaction. Particularly when the infiltrated water contains of high bicarbonate concentrations.

The samples, runoff water, groundwater of different aquifers (B4 of F1054 and B2/A7 of F1274), mixing of different water samples (Table 4 and 5) are under saturated with respect to Gypsum, Anhydrite and Magnesite.

Rainfall is under saturated with respect to Aragonite, Dolomite, Calcite, Gypsum, Anhydrite and Magnesite.

Groundwater of B2/A7 is over-saturated with respect to Aragonite, calcite and Dolomite reflecting the water/ rock interaction. While the groundwater of B4 aquifer is only oversaturated with respect of Dolomite (Table 6).

The results of mixing surface runoff water to the groundwater of B4 and B2/A7 indicating over-saturated with respect to calcite.

In general, the theoretical mixing of surface water runoffs with ground water shows an overall upgrading of the groundwater quality. The concentrations of chloride and nitrate ions in addition to other ions were found to decrease in groundwater in most mixing processes, reflecting the overall enhancement of the quality of the original 
Table 4. Mixing results of surface runoff water and groundwater of well F1054.

\begin{tabular}{|c|c|c|c|c|c|c|c|}
\hline Solution 1 & \multicolumn{7}{|c|}{ Surface Runoff Sample } \\
\hline Solution 2 & \multicolumn{7}{|c|}{ Groundwater (F1054) } \\
\hline & \multicolumn{7}{|c|}{ Percentage of Solution 1} \\
\hline Parameter & 1.00 & 0.10 & 0.20 & 0.30 & 0.40 & 0.50 & 0.00 \\
\hline $\mathrm{pH}$ & 8.04 & 8.09 & 8.08 & 8.08 & 8.07 & 8.07 & 8.01 \\
\hline $\mathrm{T}\left({ }^{\circ} \mathrm{C}\right)$ & 18.10 & 20.98 & 20.66 & 20.34 & 20.02 & 19.70 & 21.30 \\
\hline $\mathrm{EC}(\mu \mathrm{S} / \mathrm{cm})$ & 254.90 & 502.50 & 475.00 & 448.00 & 420.00 & 393.00 & 530.00 \\
\hline $\mathrm{K}^{2+}(\mathrm{mg} / \mathrm{l})$ & 4.69 & 4.96 & 4.93 & 4.90 & 4.88 & 4.84 & 5.00 \\
\hline $\mathrm{Mg}^{2+}(\mathrm{mg} / \mathrm{l})$ & 5.70 & 9.60 & 9.14 & 8.70 & 8.30 & 7.80 & 10.00 \\
\hline $\mathrm{Ca}^{2+}(\mathrm{mg} / \mathrm{l})$ & 27.45 & 18.90 & 19.90 & 20.84 & 21.78 & 22.70 & 18.00 \\
\hline $\mathrm{Na}^{+}(\mathrm{mg} / \mathrm{l})$ & 14.48 & 64.40 & 58.90 & 53.30 & 47.80 & 42.20 & 70.00 \\
\hline $\mathrm{Cl}^{-}(\mathrm{mg} / \mathrm{l})$ & 10.60 & 73.00 & 66.10 & 59.10 & 52.20 & 45.20 & 80.00 \\
\hline $\mathrm{SO}_{4}^{2-}(\mathrm{mg} / \mathrm{l})$ & 15.40 & 27.60 & 26.30 & 24.90 & 23.50 & 22.20 & 29.00 \\
\hline $\mathrm{HCO}_{3}^{-}(\mathrm{mg} / \mathrm{l})$ & 114.10 & 114.10 & 114.10 & 114.10 & 114.08 & 114.06 & 114.04 \\
\hline $\mathrm{NO}_{3}^{-}(\mathrm{mg} / \mathrm{l})$ & 3.51 & 1.25 & 1.500 & 1.75 & 2.00 & 2.25 & 1.00 \\
\hline
\end{tabular}

Table 5. Mixing results of surface runoff water and groundwater of well F1274.

\begin{tabular}{|c|c|c|c|c|c|c|c|}
\hline Solution 1 & \multicolumn{7}{|c|}{ Surface Runoff Sample } \\
\hline \multirow[t]{2}{*}{ Solution 2} & \multicolumn{7}{|c|}{ Groundwater (F1274 ) } \\
\hline & \multicolumn{7}{|c|}{ Percentage of Solution 1 in the Mixture } \\
\hline Parameter & 1.00 & 0.10 & 0.20 & 0.30 & 0.40 & 0.50 & 0.00 \\
\hline $\mathrm{pH}$ & 8.04 & 7.55 & 7.60 & 7.66 & 7.72 & 7.70 & 7.50 \\
\hline $\mathrm{T}\left({ }^{\circ} \mathrm{C}\right)$ & 18.10 & 21.60 & 21.22 & 20.83 & 20.44 & 20.05 & 22.00 \\
\hline $\mathrm{EC}(\mu \mathrm{S} / \mathrm{cm})$ & 255.00 & 1600.00 & 1450.00 & 1301.00 & 1152.00 & 1003.00 & 1750.00 \\
\hline $\mathrm{K}^{2+}(\mathrm{mg} / \mathrm{l})$ & 4.69 & 23.86 & 21.70 & 19.60 & 17.50 & 15.30 & 26.00 \\
\hline $\mathrm{Mg}^{2+}(\mathrm{mg} / \mathrm{l})$ & 5.70 & 36.12 & 32.70 & 29.30 & 26.00 & 22.60 & 29.50 \\
\hline $\mathrm{Ca}^{2+}(\mathrm{mg} / \mathrm{l})$ & 27.40 & 112.50 & 103.10 & 93.60 & 84.10 & 74.70 & 122.00 \\
\hline $\mathrm{Na}^{+}(\mathrm{mg} / \mathrm{l})$ & 14.40 & 171.55 & 154.10 & 137.00 & 119.00 & 101.70 & 189.00 \\
\hline $\mathrm{Cl}^{-}(\mathrm{mg} / \mathrm{l})$ & 10.63 & 273.70 & 244.50 & 215.20 & 186.10 & 156.00 & 303.00 \\
\hline $\mathrm{SO}_{4}^{2-}(\mathrm{mg} / \mathrm{l})$ & 15.36 & 358.00 & 320.00 & 282.00 & 244.00 & 206.00 & 396.00 \\
\hline $\mathrm{HCO}_{3}^{-}(\mathrm{mg} / \mathrm{l})$ & 114.10 & 272.40 & 254.80 & 237.00 & 220.00 & 202.00 & 290.00 \\
\hline $\mathrm{NO}_{3}^{-}(\mathrm{mg} / \mathrm{l})$ & 3.51 & 1.25 & 1.50 & 1.75 & 2.00 & 2.25 & 1.00 \\
\hline
\end{tabular}

Table 6. Saturation Indices (S.I) for different water samples.

\begin{tabular}{|c|c|c|c|c|c|c|}
\hline Water Sample & $\begin{array}{c}\text { S.I } \\
\text { Calcite }\end{array}$ & $\begin{array}{c}\text { S.I } \\
\text { Aragonite }\end{array}$ & $\begin{array}{c}\text { S.I } \\
\text { Dolomite }\end{array}$ & $\begin{array}{c}\text { S.I } \\
\text { Anhydrite }\end{array}$ & $\begin{array}{c}\text { S.I } \\
\text { Gypsum }\end{array}$ & $\begin{array}{c}\text { S.I } \\
\text { Magnesite }\end{array}$ \\
\hline Rainfall & -0.890 & -1.050 & -2.260 & -2.930 & -2.68 & -2.17 \\
\hline Runoff (Flood water) & 0.080 & -0.070 & -0.060 & -2.870 & -2.63 & -0.90 \\
\hline Groundwater (F1274) & 0.430 & 0.290 & 0.770 & -1.220 & -0.99 & -0.31 \\
\hline Groundwater (F1054) & -0.029 & -0.175 & 0.096 & -2.834 & -2.60 & -0.549 \\
\hline 0.5 Runoff +0.5 GW (F1274) (Mixing) & 0.090 & -0.050 & -0.001 & -1.570 & -1.35 & -0.66 \\
\hline 0.5 Runoff +0.5 GW (F1054) (Mixing) & 0.035 & -0.110 & 0.040 & -2.830 & -2.58 & -0.715 \\
\hline
\end{tabular}


groundwater.

\section{Conclusions}

Ten vertical electrical resistivity soundings (VES) have been used to investigate the subsurface hydro-geological conditions (to a depth of about $100 \mathrm{~m}$ ) in Wadi Al-Butum sub-catchments area for groundwater artificial recharge purposes. Adjacent boreholes, historical and recent analyzed chemical analyses of rainfall, surface water and groundwater of two aquifer types' samples were also available.

Interpretation of geoelectrical data indicates the presence of near-surface potential layer of alluvial deposits to store and recharge the shallow limestone aquifer. The thickness of this layer was found to be $35 \mathrm{~m}$ in the western part of study area (beneath VES4) and around $10 \mathrm{~m}$ at the most eastern part at VES7. Moreover, a highly potential alluvial paleo-channel deposits $(20 \mathrm{~m})$ for groundwater recharged is found at VES5. The results of hydrogeochemical modeling, saturation indices and rock/water interactions indicate an overall enhancement of the original ground quality could be expected.

\section{Acknowledgements}

The author sincerely acknowledges Prof. Elias Salameh from university of Jordan for the great valuable collaboration and suggestions. Special thanks for my colleagues Adnan Rizg, Mo'ns Al-Alwneh and Majdi Al-Sirhan for their great cooperation during field works. Critical and constructive review of the manuscript by the reviewers is greatly treasured.

\section{REFERENCES}

[1] Ministry of Water and Irrigation (MWI) Open Files, Jordan, 2011. www.mwi.gov.jo

[2] E. N. Salameh and H. Bannayan, "Water Resources of Jordan. Present Status and Future potentials," Fridrich Ebert Stiftung, Amman, Jordan, 1993.

[3] R. A. Al-Adamat, "GIS as a Decision Support System for Siting Water Harvesting Ponds in Jordan," Journal of Environmental Assessment Policy and Management, Vol. 10, No. 2, 2008, pp. 189-206. doi:10.1142/S1464333208003020

[4] UNPD, "Sustaining Water: An Update World Population Prospects, the 1994 Revision. The United Nations, New York," In: M. Shahin, Ed., Water Resources and Hydrometeorology of the Arab Region, Netherlands, 2007, pp. 525-526.

[5] A. R. Freeze and A. J. Cherry, "Groundwater," PrenticeHall, Englewood Cliffs, 1979.
[6] M. Shahin, "Water Resources and Hydrometeorology of the Arab Region," Springer, the Netherlands, 2007.

[7] M. F. Abu-Taleb, "The Use of Infiltration Field Tests for Groundwater Artificial Recharge," Environmental Geology, Vol. 37, 1999, pp. 64-71. doi:10.1007/s002540050361

[8] M. Israil, M. Al-hadithi and D. C. Singhal, "Application of a Resistivity Survey and Geographical Information System (GIS) Analysis for Hydro-Geological Zoning of a Piedmont Area, Himalayan Foothill Region, India," Hydrogeology Journal, Vol. 14, 2006, pp. 753-759. doi:10.1007/s10040-005-0483-0

[9] H. R. Al-Amoush, "Hydro-Geophysical Investigations for the Purposes of Groundwater Artificial Recharge in the Jordan Valley Area," Ph.D. Dissertation, University of Jordan, Amman, 2006.

[10] Department of Meteorology (DOM) Open Files, Jordan, 2011.

[11] Department of Meteorology (DOM) Open Files, Jordan, 2003.

[12] A. Quennell, "The Structure and Evolution of the Dead Sea Rift," Quarterly Journal of the Geological Society, Vol. 64, 1959, pp. 1-24.

[13] S. M. McDonald and Partners in Cooperation with Hunting Geological Survey Limited, "East Bank Water Resources," Ministry of Water and Irrigation, Amman, Vol. 5, 1965, p. 512.

[14] Natural Resources Authority (NRA) Open Files, Jordan 2004.

[15] J. H. Powell, "Stratigraphy and Sedimentation of the Phanerozoic Rocks in Central and South Jordan: Part BKurnub, Ajlun and Belqa Groups," Natural Resources Authority (NRA), Amman, Geological mapping Division, Bulletin 11B, 1989, 130 p.

[16] R. Kirsch and K. Ernstson, "Geoelectrical Methods," In: R. Kirsch, Ed., Groundwater Geophysics, a Tool for Hydrogeology, Germany, 2006, pp. 85-116.

[17] E. Orenella and H. M. Mooney, "Master Tables and Curves for Vertical Electrical Sounding over Layered Structures," Interciencia, Madrid, 34 p.

[18] B. P. A. Vander Velpen and R. J. Sporry, "RESIST. A Computer Program to Process Resistivity Sounding Data on PC Compatibles," Computer and Geosciences, Vol. 19, No. 5, 1993, pp. 691-703. doi:10.1016/0098-3004(93)90102-B

[19] A. Zohdy and R. J. Bisdorf, "Programs for the Automatic Processing and Interpretation of Schlumberger Sounding Curves in Quick Basic. U.S.G.S," Open File Report, 89137-2, 1989, 64 p.

[20] A. L. Bloom, "Geomorphology a Systematic Analysis of Late Cenozoic Land Forms," Prentice Hall, Englewood Cliffs, 1978.

[21] L. Calmbach, "HYDROWIN Software Version 3," Institute de Mineralogy, Lausanne, 1995. 